\title{
The Plight of Women Against Housing Challenges in the Eastern Cape Province of South Africa ${ }^{1}$
}

\author{
Dr. Henry Jacob Festus Ssekibuule D. Admin \\ Chief Policy Analyst Research and Development \\ Office of the Executive Mayor OR Tambo DM \\ E-mail: henry@ ortambodm.org.za; hssekibuule@gmail.com; Ssekibuule@yahoo.com
}

Received: Aug. 20, 2019 Accepted: Sep. 20, 2019 Online published: Nov. 8, 2019

doi:10.5296/jpag.v9i4.15781 URL: https://doi.org/10.5296/jpag.v9i4.15781

\section{Henry Jacob Festus Ssekibuule,}

Much of what has been written about the plight of women against housing challenges in the Eastern Cape Province of South Africa touches day to day issues which are affecting the social and economic hindrances bearing in mind the historical difficulties of women in South Africa during the apartheid years to participate in the main stream of the economy. However, despite considerable collaborative activity there is little evidence that clearly links collaboration to improvements in service-user outcomes or reduced inequalities. In this article I draw on literature from critical public policy and governance studies to recast collaboration as an expression of cultural performance associated with a rather different set of values and measures. I argue that understanding collaboration in the round means that we need to pay attention to all dimensions of performance including cultural performance. I argue that for over 22 years of democracy, human rights violation and excessive problems of homelessness are still a sorry state of affair despite progressive improvement in human settlement this in turn helps to explain the persistent appeal of collaboration amongst policy makers and practitioners.

\begin{abstract}
This paper touches day to day social and economic issues affecting women bearing in mind the historical difficulties of women in South Africa during the apartheid years to participate in the main stream of the economy was without iota of doubt incomprehensible and thought-provoking precisely because women were not permitted to have their own houses. The paper unapologetically provides an empirical narrative account of the plight of women in housing. The paper argues that the notion of housing in South Africa is still one of the

\footnotetext{
1 This article is drawn from Dr Henry Festus Ssekibuule book published recently in 2015 entitled 'Women Participation in Housing Re-examined, Wandsbeck, South Africa: Reach Publishers
} 
greatest challenges in the post 1994 dispensation due to an extremely complicated and disintegrated bureaucratic system that was inherited from defunct non-operational apartheid government. Issues of homelessness, unemployment, poverty and inequality are crucial to understand why women rights were violated and accounts for the reason for transformative shift to restorative justice in the post-apartheid democracy. Over 22 years of democracy, human rights violation and excessive problems of homelessness are still a sorry state of affair despite progressive improvement in human settlement. The qualitative study relies not only on historical facts but also triangulated empirical evidence of what was observed and engaged with key informants interviewed to made compelling conclusions and propositions about the plight of women in South Africa, especially in the Eastern Cape Province.

Keywords: public participation, poverty, inequality, human settlement, self-help, empowerment, housing project, informal settlement, funding

\section{Introduction and Background}

Housing problem in South Africa dates back from the colonial era to apartheid and straddles through post-apartheid South Africa. The main argument in this paper is an interpretation of how previous state structures, with associated spatial practices, have influenced housing delivery in post-apartheid South Africa, which led to the inclusion into the constitution of a right to have access to adequate housing. Despite this constitutional imperative, housing remains a challenge in South Africa.

The Eastern Cape has the third largest provincial population in the country. What is today the Mdantsane Township, the second largest township in South Africa after Soweto, was born out of the architect of apartheid which pushed black people into the periphery, and women were even a worse case. The legacy of apartheid is now, today, causing unstable movement from rural to urban areas, in which Mdantsane is seen to be mushroomed, leaving the delivery of housing under serious stress to accommodate everyone. In doing away with the legacy of the painful past, women should play a role and be involved in every decision in the mainstream of the economy. Housing projects should be built at the standard that does not compromise human dignity and respect of the black people, who equally deserve a decent life, and their livelihood should be of good quality no matter where they are in rural areas, townships, town and cities.

It is the basis of this paper to nuance the plight of women in the ensuing discussion underpinned by social theories and empirical evidence. Unfortunately, even today, after 20 years of democracy, women are still struggling; they have the rights, but their rights have not yet translated into meaningful quality living experiences.

\section{Social Theories}

Social theory informs our understanding of issues that, in turn, assists in making decisions and sense of the world around us. In other words, there is a constant relationship that exists between housing and the social theory. (Almond,1988:872) states that it is fairly clear that there can be no return to the state in any simplistic political reductionism that ignores women to participate in housing delivery programmes or neglects wider social forces and their 
operations through the state to determine or influence rural housing. The state reacts to the preference of electors, but such inactive views of the state intervention are unsatisfactory. It should no longer be good enough for any study of housing to be undertaken without first explicating a position on the extent to which the state is seen as an autonomous actor in housing delivery.

Modernisation scholars held the view that social change was evolutionary and it would take generations to complete and its profound impact would be felt only through time (Chinchilla, 1983). These modernisation scholars drew their assumptions from the functionalist theory, which emphasised the interdependence of social institutions, the importance of pattern variables, at the cultural level, and the built-in process of change through homeostatic equilibrium. (Parsons, 1966) was one such theorist. Among other things, modernisation meant the transformation of communal land ownership to a system of private ownership. In housing, modernisation meant the adoption of industrialised housing based on Western culture and technical standards. The dominant form of shelter was conventional housing and this led to the bulldozing of slums and rehousing of the occupants in public housing (Burgess, 1982; Hardoy \& Satterthwaite, 1989).

Later critiques of modernisation arose from scholars of opposing ideological leanings (Alvin, 1991; Valenzuela and Valenzuela, 1993). Samuel Valenzuela and Arturo Valenzuela state that modernisation theory relied on a reductionist approach, inadequate for the study of a complex phenomenon such as development or underdevelopment (Valenzuela \& Valenzuela, 1993). (Brohman, 1995) says that the neglect of culture and ethno development was not an oversight of mainstream theories, but a paradigmatic blind spot. The socio-cultural context within which economic processes were shaped was ignored in the Universalist concepts developed by neo-classical theory and related frameworks. Pointing to the North-South dynamics, Brohman (1995) maintains that modernisation theory lacked both an input from the South itself and provided an inadequate analysis of social relations and structures in specific countries, ignoring patterns of discrimination and inequalities based on social class, ethnicity and gender, to mention but a few.

Neo-classical critiques of modernisation gave rise to two development strategies, the basic need approach and redistribution with growth in the 1970s and 1980s respectively (Burgess, 1992). The underlying assumption was that growth could be achieved by addressing the triple problems of poverty, unemployment and inequality (PUI). The right wing supply-side economics that underpinned these strategies was critical of the Keynesian basis of modernisation, which argued that development problems were a result of insufficient aggregate demand. The redistribution with growth strategy posed that the objectives of growth and equity were not in conflict. Growth could be achieved by focussing on the growth of incomes of the targeted poverty groups such as women. Incomes could be improved through transfers and subsidies and improved access to goods and services such as water, electricity, roads, housing, health and education. The basic goal of redistribution was an improvement in the absolute incomes of the poor rather than the redistribution of existing assets, output and employment of the poor and labour-intensive measures aimed at increasing productivity. This resulted in the adoption of self-help housing in the 1970s. 
To this end, the liberal neo-classical view says that the housing problem is a result of natural causes such as population growth, but it is not these pressures alone that are to blame. It is the interventionist and discriminatory policies, as well as the more recent patent lack of policy or action on the part of the government, which have exacerbated the problem to the extent that it has become a crisis. The legacy of apartheid in the very form of the city itself is a sustaining factor and major barrier to solving the problem. The neo-classical vision is that, in setting out to solve the housing shortage by freeing up the housing market, the production of housing will become a major stimulator of economic growth in the country and thus solve many other economic problems at the same time.

This neo classical view was however objected to by the neo-Marxists in their attempt to explain the housing crisis in South Africa. The neo-Marxists have a refreshingly radical view of the past and a rather visionary view of the future. Their solutions are revolutionary and much wider in their implications for a changed society. This possibly makes these solutions less useful as long as the present economic system remains in place. Where their solutions are relevant to present changes that are being implemented, it is in the emphasis of redressing past injustices. Their analytical framework could also be of great value in avoiding the inherent inequalities of past systems and policies. There is no doubt that the women participation in housing delivery problem in South Africa is complex in origin and difficult to solve. It is for this reason that Davids et al (2005:9) emphasises the need to consider public participation approaches that promote women participation in development.

\section{Empirical Analysis}

Early on the morning of 24 March 2012, I set off from the university in search of the urban housing projects. As I drove around the urban areas, I wondered how the use of traditional rondawel architect was thought through. These urban areas of the defunct Ciskei are comprised mainly of scattered and occasional closer settlements. In this area, most houses were linked to gardens of varying size. As I drove further on the poorly maintained dirt roads, I wondered how the Eastern Cape Department of Housing officials would engage villages in alternative models for urban housing design. I also wondered how housing development would be connected to farming and urban livelihood pursuits and problematic issues of insecure tenure would be introduced and discussed. I also reflected on questions of governance and authority and the fraught relationships between traditional leaders who controlled land allocation whilst local government officials controlled housing project funding.

Nearly half of the key informants are still waiting for the government to provide them with houses, since it is a very slow process for them to obtain these houses. An interview with a household in Hipellcrest Extension (2008) lamented that:

"This community has lost hope, our complaints have not been received and they serve nothing. There is no response by anyone. The role of the municipality should make sure that delivery of houses is speeded up - 
this project developed very slowly."

This shows that the problem of housing is still enormous and most people need housing to deal with problems of inadequate shelter, homelessness and poverty in low income areas in the Buffalo City Metropolitan Municipality. Some key informants who are renting the houses do not have sufficient income to sustain their living. There are also no measures put in place to help the poor realise their housing rights and ensure that they acquire decent housing. Key informants state that houses are given to unintended beneficiaries, whereas the deserving beneficiaries are left out. Some people have multiple ownership of housing, whilst others do not have access to any.

About $40 \%$ of the key informants cited inequality and discrimination of the disabled people in attaining the RDP houses. At least $70 \%$ of the interviewees raised concerns over the exclusion of women. Women are not recognised as household owners. Hence, it can be very difficult for most of the women to acquire government free housing facilities in the local areas in the Mdantsane Township. As stipulated by the local government, the eligibility criterion is based upon a person being a South African citizen. However, 75\% of the key informants asserted that foreigners are currently occupying some RDP houses in the local areas. This shows some irregularities in the provision of housing as Meyer (2000:86) argues that bias and incompetence rock the municipality administering these houses; hence, targeted areas and vulnerable groups such as women, the elderly persons and the disabled are not sufficiently catered for.

According to the study, $95 \%$ of the key informants in the Mdantsane Township, most of who were women, find it harder to gain access housing, which was allocated by ability to pay rather than by housing need. Changes to housing policies since 1962 made it increasingly difficult to gain access to public sector housing and there was greater emphasis on finding housing in the private sector, especially through owner occupation. Such a trend causes increasing disadvantage to women. Ninety-five percent of the key informants from the Mdantsane Township disagreed that available funds were adequately spent for housing development, since their houses are on the verge of collapse. Constant review of the delivery of houses and housing services was of paramount importance in our contemporary and fast-growing society. Key informants would like to see improvements made to their houses that were built some fifty years ago. According to the study, $95 \%$ of key informants from the Mdantsane town were of the view that housing services were not continuously monitored by the municipality; thus, everything is falling apart without help and response.

The study has also revealed that women were not satisfied with the pace, the quantity or the quality of houses built for them. They're too small to accommodate their traditional functions such as weddings, circumcision, heritage days and any other special occasions. It has shown that $96 \%$ of the key informants were Xhosa women, most of whom were pensioners, who are forced to stay with their grandchildren since most of the parents have either died as result of the scourge of HIV/AIDS or travelled to Cape Town, Johannesburg or Durban to look for greener pastures - jobs - or umsebenzi, as it is called in Xhosa. Young women do not wish to remain in the family home or find that they are unable to stay there because of personal 
circumstances. They have a very limited range of housing options available according to the current housing policy of South Africa. Homeless young women have no right to accommodation under homeless legislation. Many beneficiaries agreed that they were facing serious challenges pertaining to the low-cost houses allocated to them. They also reported that, since they had applied for housing in 1998 and 1999, they had not received any report on the progress of their applications until 2003 when the Provincial Department of Local Government and Housing started to revive the housing project. Most of the beneficiaries indicated that they used to go to the department to enquire about their status of housing provision. They indicated that, due to the lack of information in terms of the project, some of the people were unable to resort to other means of getting accommodation such as renting to accommodate their families. The other challenge was that most of them were not working and it was difficult for them to get money for transport to the department to make inquiries about their applications.

Table 1. Low Income Housing List

\begin{tabular}{ccc}
\hline Year & $\begin{array}{c}\text { Total number of those on the } \\
\text { waiting list }\end{array}$ & Number of stands allocated \\
\hline 2002 & 1946 & 834 \\
2003 & 3017 & 1079 \\
2004 & 4740 & 2065 \\
2005 & 5313 & 2860 \\
2006 & 6430 & 3795 \\
2007 & 6956 & 3800 \\
\hline
\end{tabular}

Source: Buffalo City Metro Municipality: Department of Housing, 2008

The stats presented here show that there was a huge demand for housing in these urban areas. One sees from the stats that the housing waiting list has been growing over the years. In 2002, for example, there were 1946 people on the waiting list and the corresponding figure for the stands allocated was 834. As the waiting list increased, the number of stands allocated decreased, which meant that the figure for stands or houses stayed very low. The key informants (KI) expressed the concern that some applicants either become inactive or completely drop from the housing list because they would not know about their chances of owning a house. As such, this brought about substandard illegal structures built in the hope of awaiting the long spell for housing delivery.

Many key informants pointed at the inefficiency of the local municipality in providing housing to the urban populace as the main reason for inadequate housing delivery in the area. One respondent states that:

"I am not happy with them: they call us for meetings, promise this and that, even thing they know they cannot deliver."

While beneficiaries appreciate that the government built houses for them, they were still not satisfied, as a number of problems are still eminent in the area. Community participation, if employed, will presumably ensure that the deserving people get the houses they deserve 
without nepotism.

There are several factors that prevent communities from participating in housing provision. These include lack of information and lack of understanding of the roles and responsibilities of various stakeholders in local governance. The community representatives interviewed felt that the top-down bureaucratised and centralised strategies of addressing issues of housing has led to the poor planning and implementation. Moreover, the apparent inaccessibility and lack of visibility on the part of officials in the community has meant that the needs of the vast majority of people were largely unresolved. The community members interviewed in this study emphasised great concern on the absence of regular feedback from meetings with representatives of the community groups, demonstrating unwillingness on the part of the government officials to share their decisions made. Some meetings and workshops do not accommodate all the people, for they are convened during working hours instead of being held after hours and closer to the communities. Generally, community organisations and councillors have not developed strong relationships based on clearly defined terms and roles and participatory decision-making in keeping the community informed. Most key informants said that the process of women participation in local government is complex and must be addressed at several levels. Access to quality housing should not be understood as a privilege to be enjoyed by a few. Women participation should be used as a means of empowering communities. This implies that community involvement should be understood as to benefit communities not only through the development itself, but by establishing a relationship with the community that will ensure sustainable growth: "If communities are participating in the whole process and are seen as important partners, they are more likely to feel that they are part of the housing delivery ownership. Pieterse (2001) contends that public participation gives people a better understanding of their own interest and the interest of others and, in some cases, brings them to see what would be best for the entire group.

One argues that it is not sufficient to support women's empowerment in policy while sabotaging their participation at the implementation level. One way to reconcile policy and practice is to recognise their role in the production and distribution of material in their own communities. The government bodies could move a step further and give contracts to women to supply building material in the construction of government-funded utilities such as schools, halls, clinics and any other projects. Bypassing women, who are the local material suppliers in the community, denies the opportunity for local economic development. However, supporting women would benefit the whole community, for it would result in more employment and more money to spend, and, therefore, result in sustainable local economic growth. The other factors that contributed to the decline in housing provision in the Mdantsane Township can be attributed to the unequal land ownership, discriminatory land use regulations and insecure land tenure systems, which marginalised the majority of the urban and urban poor populations. This is supported by Maqhasha (2003:43), who writes that, since people do not have access to land, this fact inhibits their access to housing, whereas housing is a right.

The process of acquiring land and letting people build houses is significant, because it provides the poor with access to security of tenure and encourages them to progressively 
build or extend quality standard houses and increasingly improve their infrastructure. The legacy of racially unequal land control that confronted the former settler colonies was, at independence, maintained through constitutions that guaranteed the protection of private property and sanctified yet aborted 'willing buyer, willing seller' approaches to the redistribution of freehold land. More harm to the housing service delivery was the neo-liberal tendency of the South African Government to enhance a market-based economy or rather gradualist approach to land reform. One argues therefore that there must be equitable distribution of land and the state must acquire more land for housing projects and to ensure that interplay of intergovernmental relations within and across the spheres of government is effective.

Key informants argued that duplication of housing institutions and funding mechanisms caused tremendous constraints in delivery. They said that:

"Fragmentation of the housing function racially between the previous own affairs administration and the department of housing has resulted in a large amount of overlap, duplication and confusion within and between housing institutions, which results in significant inefficiencies and wastage."

Tomlinson (1999:76) states that project-linked housing has relied on assumptions that: those communities could be active participants in the projects and equal partners with the developers through social compacts and banks would grant low-income households credit to finance construction of a structure once they had obtained their serviced lots. Unfortunately, this has not been the case.

\section{Funding Model for Housing Projects}

The local municipality gets the majority of its revenue from the public. Due to funding constraints, it is difficult to provide services to the communities to their satisfaction. This view is also echoed by Park (1998:6), who states that lack of financial support for the housing sector has made attempts to increase housing supply ineffective. According to a local government official, about 35\% of the Mdantsane Township's revenue comes from other sources or donors, as the private sector is also involved in funding housing projects in low income areas. The budget allocation from the state, singlehandedly cannot meet the housing expectations in the area. The system is driven by narrow budget allocations, not actual human settlement need. However, the stakeholders themselves are providing little to enhance housing projects.

Considering that Buffalo City Metro Municipality has more than 21 housing projects, with an estimated 4000 approved beneficiaries, it will be very difficult for the municipality to reach these targets. The annually allocated budget for the municipality is not sufficient to spearhead housing projects to its surroundings. Delivery mechanisms are bureaucratic and slow, hence the available housing budgets are persistently under-spent. Currently, the major sources of income for the Buffalo City Metro Municipality are the land rents from people who occupy council houses. Most key informants cited lack of funding as the major challenge faced by the local municipality to effectively deliver social services such as housing to the people. 
Even the money or funds acquired from banks which have sponsored some housing projects, and other stakeholders, are not enough to help deliver cost-effective services that meet minimum standards. Buffalo City Metro Municipality's lack of funding has affected service delivery to its surrounding areas and that made it unable to meet the housing demand of its people.

Key informants argued that duplication of housing institutions and funding mechanisms caused tremendous constraints in delivery. They said that:

"Fragmentation of the housing function racially between the previous own affairs administration and the department of housing has resulted in a large amount of overlap, duplication and confusion within and between housing institutions, which results in significant inefficiencies and wastage."

With the initiation of the RDP (1995), the government increased its allocation to the municipalities from 1995 to 2002 . However, from the period 2004 up to date, the government has suspended these allocations and consequently has not been providing sufficient funds to the municipality to build houses for the people. This impedes the provision of housing to the intended beneficiaries. The role of the municipality as the implementing agency has been affected by lack of funding. About $90 \%$ of the key informants indicated that some projects have been blocked and others have undergone several years without completion due to lack of funds, examples being the Ntselamanzi and Alice Golf course housing projects run by the Buffalo City Metro Municipality. These projects have been severely affected due to some financial difficulties. However, all efforts to overcome this stumbling block are being undermined by key factors such as corruption and financial mismanagement that are entirely avoidable.

Key informants further argued that lack of end user finance is one of the contributing factors in housing delivery. The unavailability of end user finance, especially for low income households, impedes the ability of many households to access adequate housing even though they might be able to afford it. They agreed that housing delivery is essential to improve the lives of ordinary citizens. The unavailability of end user finance, the need for bridging finance for developers and a lack of institutional sources or funding for bulk infrastructure provision all presented enormous challenges, which were sure to persist circumstantially. Financing urban housing remains the greatest challenge in post-apartheid era. Self-help constructions can help to strengthen community-based organisations and this helps the poorest to be involved in grassroots organisations and community decision-making. Financial rigor might be beneficial in order to strengthen community processes in housing delivery. Community participation becomes a key to socio-economic development, particularly when the government has limited administrative and financial capacity to service all sectors of the population.

\section{Conclusions and Propositions}

It is evident from the analysis of the theoretical and empirical evidence that the Eastern Cape Provincial Government need to speed up the process of adequate human settlement. Some of 
these challenges could have been averted if the beneficiaries meaningfully participated in the initial human settlement planning process. Overall, one infers that women's roles in housing development cannot be fully understood by examining their roles at the implementation level only. An analysis of their roles in decision-making, implementation, post-implementation such as monitoring and evaluation and the various aspects related to housing is absolutely necessary in order to fully understand their plight. Therefore, the discrepancy between policy and practice is critical and needs urgent resolve to involve women in all stages of the policy cycle. At the helm of policy level, issues of integrated development planning needed to be considered in human settlements and the roles of the housing department and other government agencies providing housing should be further clarified.

It comes very strongly that women are very active and important players in society and their exclusion from decision-making, be it housing, especially human settlement or the mainstream economy, will do more harm than good. The legacy of apartheid and the stubborn stereotypes created should be shunned and done away with to maximally increase the representation of women in decision-making processes of the state in all spheres of government. Already, in the post-apartheid society, women involvement in decision-making is crucial, but that needs to be accelerated so that their representation is significantly acceptable. This is possible if women are recognised, equipped with technical and functional skills and empowered to take ownership of the housing projects through a bottom-up approach. I argue that women should be incorporated in the decision-making system throughout all stages of the policy cycle (policy making, implementation, monitoring and evaluation) to have tangible and intangible meaningful outcomes. This is achievable if the proper funding model is also brought to the equation.

\section{References}

Almond, G. A. (1988). The return to the state. American Political Science Review, 82(3), 853-874. https://doi.org/10.2307/1962495.

Chinchilla, N. S. (1983). Interpreting social change in Guatemala: Modernization, dependency, and articulation of modes of production. Theories of Development, 139-178.

The Constitution of the Republic of South Africa. (1996). Cape Town, Juta Law.

The Republic of South Africa. (1994). White Paper on Housing. Pretoria, Government Printer.

The Republic of South Africa. (1998). Housing Act, Act 36. Pretoria, Government Printer.

The Republic of South Africa. (1998). Local Government, Municipal Structures Act, (Act 117 Pretoria, Government Printer.

Tomlinson, M. R. (1999). South Africa's housing policy: lessons from four years of the new housing subsidy scheme. Third World Planning Review, 21(3), 283. https://doi.org/10.3828/twpr.21.3.n72w4p14881v7221.

Valenzuela, J. S., \& Valenzuela, A. (1978). Modernization and dependency: Alternative 


\section{Macrothink}

Journal of Public Administration and Governance ISSN 2161-7104 2019, Vol. 9, No. 4

perspectives in the study of Latin American underdevelopment. Comparative politics, 10(4), 535-557.

Burgess, R. G. (Ed.). (2003). Field research: A sourcebook and field manual. Routledge.

Chilcote, R. H., \& Johnson, D. L. (1983). Theories of development: mode of production or dependency?. Sage Pubns.

Davids, I., Theron, F., \& Maphunye, K. J. (2005). Participatory Development in South Africa: A Development Management Perspective. Pretoria, South Africa: Van Schaik Publishers.

Hardoy, J. E., \& Satterthwaite, D. (1989). Squatter citizen: life in the urban third world. London, Routledge.

Maqhasha, L. (2003). Current trends, facts and perspectives on policy transformation: the case of housing delivery with special reference to Cape Town.

Parsons, T. (1966). Societies: Evolutionary and comparative perspectives. Englewoodliffs, New Jersey, Prentice Hall.

Pieterse, J. N. (2001). Development theory: deconstructions/reconstructions. Sage publications, London.

\section{Copyright Disclaimer}

Copyright for this article is retained by the author(s), with first publication rights granted to the journal.

This is an open-access article distributed under the terms and conditions of the Creative Commons Attribution license (http://creativecommons.org/licenses/by/4.0/). 